\title{
Renovation of Seeded Warm-season Pastures with Atrazine
}

T.O. DILL, S.S. WALLER, K.P. VOGEL, R.N. GATES, AND W.W. STROUP

\section{Abstract}

Numerous warm-season pastures have been established in the last 30 years in the central Great Plains. Some of these pastures are old enough to verify that they can be abused by overgrazing as easily as native tallgrass prairies. Overgrazed warm-season pastures are invaded and dominated by cool-season grasses such as smooth brome (Bromus inermis Leyss.) and Kentucky bluegrass (Poa pratensis L.), which diminishes the pasture productivity during the hot summer months. Since established warm-season grasses have greater tolerance to the herbicide atrazine than coolseason grasses, the effectiveness of atraxine applications in renovating invaded warm-season pastures was evaluated. A single, early spring application of atrazine $(3.3 \mathrm{~kg} / \mathrm{ha})$ killed or sufficiently suppressed the cool-season grasses so that surviving warmseason remnants were able to effectively re-establish the warmseason pasture in a single growing season without any loss in total pasture forage production. Lower rates of atrazine were not as effective, particularly if smooth brome was the primary coolseason grass. The single atrazine application cost was approximately $25 \%$ of the seed cost associated with more conventional renovation. Pastures should not be grazed the treatment year but can be hayed at the end of the growing season. The success of the practice is dependent on the presence of warm-season grass remnants. Spraying test strips in small fenced areas would be advisable before treating entire pastures.

The eastern one-third of Nebraska was historically warm-season dominated True Prairie (Weaver 1965). Much of this land was plowed when the area was homesteaded for production of grain crops.

Many of these areas have been seeded into warm-season pastures during the last 30 years. Usual seed mixtures consist of big bluestem (Andropogon gerardii Vitman), switchgrass (Panicum virgatum L.), indiangrass (Sorghastrum nutans Nash.), sideoats grama [Bouteloua curtipendula (Michx.) Torr.], and little bluestem [Schizachyrium scoparium (Michx.) Nash]. These pastures and native rangeland are used primarily for spring and summer grazing for cow-calf herds. Some of the seeded pastures are old enough to verify that overgrazing is a factor on seeded pastures as well as on native tallgrass prairies. This results in invasion and dominance by smooth brome (Bromus inermis Leyss.) and Kentucky bluegrass ( Poa pratensis L.).

Recently Samson and Moser (1982) demonstrated the effectiveness of a spring application of atrazine [2-chloro-4-(ethylamino)-6(isopropyl amino)-s-triazine] in shifting the composition of native rangeland dominated by Kentucky bluegrass to warm-season remnant big bluestem and sod-seeded switchgrass in a single growing season. Waller and Schmidt (1983) also shifted species composition in native rangeland from a Kentucky bluegrass and smooth brome dominated mixture to one dominated by remnant warmseason grasses, primarily big bluestem, by a single spring applica-

\footnotetext{
Authors are county extension agent, Cooperative Extension Service, Stapleton, Neb.; professor, Dep. of Agronomy; supervisory research geneticist, USDA-ARS graduate research assistant, Dep. of Agronomy; and associate professor, Biometrics and Information Systems Center, Univ. of Nebraska, Lincoln, 68583. Gates is currently assistant professor Iberia Research Station, Louisiana State University Agricultural Center, Jeanerette 70544.

Research is based on a thesis presented by T.O. Dill to the faculty of the Graduate College of the Univ. of Nebraska in partial fulfillment of the requirements of the M.S. degree. This paper is published as Journal $\$ 7680$ of the Nebraska Agricultural Experiment Station.

The authors express appreciation to Mr. LaMoine Brownlee, (retired) supervisory agronomist, Roman L. Hruska, U.S. Meat Animal Research Center, Clay Center, Neb., for his assistance in this research.

Manuscript accepted 14 May 1985.
}

tion of atrazine.

The purpose of this study was to determine if the seeded warmseason pastures could be renovated by using atrazine to suppress cool-season competition. A second objective was to evaluate the use of atrazine in stands dominated by smooth brome rather than Kentucky bluegrass.

\section{Materials and Methods}

\section{Study Area}

This study was conducted in south central Nebraska $6.5 \mathrm{~km}$ west of Clay Center, on the Roman L. Hruska U.S. Meat Animal Research Center (MARC). The area is located within the True Prairie region of North America (Weaver 1965). The topography is gently rolling to nearly level. Soils are formed in deep windblown Peorian loess, with a subsoil of glacial outwash and till. The study site is mapped as Crete silt loam (fine, montmorillonitic, mesic, Pachic Arguistoll) thick solum, with 0 to $1 \%$ slope. Average annual precipitation is $69 \mathrm{~cm}$ with $80 \%$ occurring from April through September. Average growing season is $\mathbf{1 4 8}$ days and the normal grazing period on range is from 1 May to 31 October (Hammer et al. 1981).

\section{Pasture History}

There are 4,450 ha of seeded, warm-season grasses at MARC. The study areas were formerly cultivated areas with grasses seeded into milo [Sorghum bicolor (L.) Moench.] stubble in the spring of 1967. Seed mix species were 'Pawnee' big bluestem, 'Nebraska 54' indiangrass, 'Trailway' sideoats grama, 'Nebraska 27' sand lovegrass, [Eragrostis trichodes (Nutt.) Wood]; and a legume, 'Empire' birdsfoot trefoil (Lotus corniculatus L.). Annual spring and summer grazing was initiated in the spring of 1969 (L. Brownlee 1981 , personal communication). Spring applications of $73 \mathrm{~kg} / \mathrm{ha}$ ammonium nitrate $\left(\mathrm{NH}_{4} \mathrm{NO}_{3}\right)$ were made in alternating years. The overgrazing required to maintain herd size in beef cattle genetic studies allowed smooth brome to dominate the pastures. Kentucky bluegrass and annual brome (Bromus spp.) also appeared.

The study area had been in smooth brome for many years and buried seed and rhizomes may have contributed to its occurrence. Additionally, roadside vegetation at MARC is a mixture of smooth brome and Kentucky bluegrass, providing a potential seed source. These cool-season grasses could exploit the wet springs when the seeded warm-season grasses were dormant.

A grazing exclosure in one pasture was used to statistically define treatment effects over a 2-year period following a single herbicide application. The grazed portion of the pasture was used to determine the magnitude of treatment response. Additional pastures were sprayed in 3 different years to qualitatively evaluate the year effect and provide evidence of repeatability of treatment response.

\section{Grazing Exclosure}

Treatments, an unsprayed control and 1.12 .2 , or $3.3 \mathrm{~kg}$ (ai)/ ha atrazine (AAtrex 4L), were applied on 2 April 1981 within the exclosure using a conventional pressurized boom $(3 \mathrm{~m})$ sprayer. The herbicide solution was mixed for the low rate using a carrier volume of $2001 /$ ha. Multiple passes were used to achieve the 2 higher treatments. Prior to growth initiation and before treatment application, the dormant standing crop was removed by mowing and raking. This is a common practice when dormant vegetation restricts the ease and efficiency of herbicide application. For easier data collection and to reduce the effect of shading from previous 
year's growth, standing crop was also removed prior to the 1982 growing season. The experimental design was a randomized complete block with 4 replications. Plots (experimental unit) were $3 \times 6$ $\mathrm{m}$ and separated by $3-\mathrm{m}$ alleys.

Species composition data were obtained in May and Octobcr 1981 and 1982. Warm-season species were at the 2 to 5 leaf stage and easily distinguishable in May of both years. Stand density and potential production eliminated the use of more conventional line transects or ten-point frames. Ten 1-m rods used as line transects were randomly placed at right angles on either side of a line running lengthwise through the center of each plot. Relative species composition was estimated by counting basal culms of each species that intercepted the line (sampling rod). At the end of the second growing season, species composition was also determined in a similar manner outside the exclosure in the grazed portion of the pasture. Five randomly located transects $(100 \mathrm{~m})$ radiated away from the grazing exclosure and ten $1-\mathrm{m}$ rods were randomly located perpendicular to each transect. The area immediately adjacent to the fencing was excluded.

Yield (above-ground biomass) was estimated by hand clipping individual species within 3 quadrats at ground level on 3 harvest date in 1981 and 1982 . Quadrats $\left(0.2 \mathrm{~m}^{2}\right)$ were randomly located in each plot on each harvest date. Quadrats clipped in a previous sampling were not resampled. Samples were ovendried in a forced air oven for 48 hours at $68^{\circ} \mathrm{C}$ and weighed.

Preplanned, orthogonal contrasts were used to compare treatment responses (Steel and Torrie 1980). Analyses were on plot means of above-ground biomass for warm-season grasses, coolseason grasses, and total herbage. Warm-season herbage was the sum of individual yields of the key species: big bluestem and indiangrass. Cool-season herbage was the sum of the individual yields of the prominent species: smooth brome, annual bromes, and Kentucky bluegrass. Total herbage was the sum of yields for warm-season grasses, cool-season grasses, and all other aboveground vegetation. Regression analysis was used to evaluate consistency of response. A multivariate analysis was used to determine significant treatment by time interactions for shifts in relative species composition (Stroup and Stubbendieck 1983).

\section{Pasture Demonstration}

During the 3 years following treatment of the grazing exclosure, 11 entire pastures (approximately 65 ha each) received a single spring application of atrazine. Each pasture selected was characteristic of the grazing exclosure. In 1982, 3 pastures were sprayed 10 April with $2.2 \mathrm{~kg} / \mathrm{ha}$ atrazine. Five pastures were similarly treated in 1983 . Three pastures were sprayed in 1984 with $2.8 \mathrm{~kg} / \mathrm{ha}$. Pasture demonstrations were used to determine repeatability of treatment response on a production scale.

\section{Results and Discussion}

\section{Grazing Exclosure}

\section{Vegetation Composition}

Approximately $74 \%$ of the vegetation on the untreated area was smooth brome, Kentucky bluegrass, and annual bromes (coolseason grass component). Big bluestem and indiangrass (warmseason grass component) comprised only $20 \%$ of the vegetation. Other warm-season grasses present in small amounts included little bluestem, switchgrass, sideoats grama, and stinkgrass [Eragrostis cilianensis (All.) E. Mosher].

Precipitation for the 1981 growing season was consistent with the long-term average for cool-season vegetation, warm-season vegetation and vegetative year (Table 1). Consequently, results for the year of treatment for the grazing exclosure were representative of expected vegetation response to atrazine applications.

In May, approximately 5 weeks following the herbicide application, treatment effects were apparent. The highest atrazine rate had more warm-season grass composition $(P=.08)$ and less cool-season
Table 1. Seasonal precipitation (cm) and long-term average at Clay Center, Nebraska in 1981 - 1984.'

\begin{tabular}{|c|c|c|c|c|c|}
\hline \multirow{2}{*}{ Season ${ }^{2}$} & \multicolumn{4}{|c|}{ Year } & \multirow[b]{2}{*}{$\begin{array}{l}\text { Long-term } \\
\text { average }\end{array}$} \\
\hline & 1981 & 1982 & 1983 & 1984 & \\
\hline Cool-season & 35.2 & 42.6 & 42.6 & 50.6 & 32.9 \\
\hline $\begin{array}{l}\text { Warm-season } \\
\text { Vegetative }\end{array}$ & 33.1 & 32.9 & 36.1 & 22.8 & 36.9 \\
\hline year & 68.3 & 75.5 & 78.7 & 73.4 & 69.8 \\
\hline
\end{tabular}

'Data obtained from the Climatological Data for Nebraka, National Oceanic and Atmospheric Administration, National Climatic Center, Asheville, North Carolina. The long-term average was based on data from 1951-1980.

${ }^{2} \mathrm{Cool}-$ season precipitation is measured from the previous October through May Warm-season precipitation is measured from June through September. Vegetative year precipitation is measured from the previous October through September.

grass composition $(P=.09$ ). This was apparently caused by the loss of annual brome from the treated areas. It was the most atrazine sensitive cool-season competitor, exhibiting mortality within 2 weeks. Visual observation indicated that perennial species required 46 weeks to exhibit an atrazine effect. However, regression analysis indicated a lack of consistency in response across treatments $\left(r^{2}<5\right)$ for all variables.

In 1981 warm-season grass percent composition remained unchanged on the untreated plots between May and October (Fig. 1). On all areas treated with atrazine the warm-season composition

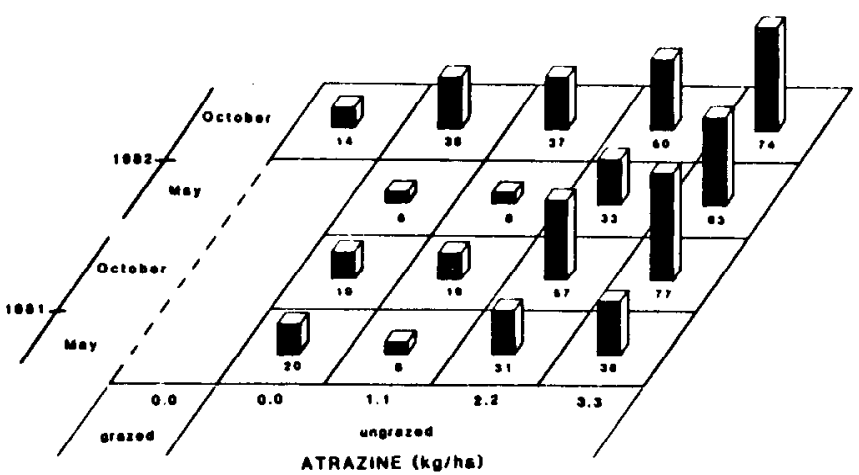

Fig. 1. Proportion of species composition contributed by big bluestem and indiangrass as influenced by atrazine rate and time after a single spring application (April 1981). The results of the linear contasts $(P>F)$ evaluating the effect of atrazine rate within the 4 sample dates beginning with May 1981 are: $.08, .01,<.01,<01$, respectively.

had increased approximately two-fold. Higher atrazine rates resulted in higher percent composition for warm-season grass composition $\left(P=.01, r^{2}=.68\right)$. There was an atrazine rate by time interaction $(P=.03)$ for the proportions of warm- and cool-season grasses, verifying the shift in species composition following atrazine treatment. Samson and Moser (1982) observed a similar shift toward warm-season grasses within the first growing season after spring applications of atrazine $(2.2 \mathrm{~kg} / \mathrm{ha})$ and paraquat $\left(1,1^{1}\right.$ dimethyl-4,41 bypyridinium ion) $(.03 \mathrm{~kg} / \mathrm{ha})$ on a Kentucky bluegrass dominated native warm-season pasture in eastern Nebraska. Additionally, Waller and Schmidt (1983) reported similar findings with atrazine $(2.2 \mathrm{~kg} / \mathrm{ha})$ alone on native, warm-season pastures dominated by Kentucky bluegrass.

One year following treatment (May 1982), the untreated plots and those treated with $1.1 \mathrm{~kg} /$ ha had nearly equal percent composition of warm-season grasses (Fig. 1). The percentage of warmseason grasses was four-fold greater on the plots treated with 2.2 
$\mathrm{kg} / \mathrm{ha}$ and nearly eight-fold greater on those treated with the 3.3 $\mathrm{kg} /$ ha rate compared to untreated areas. Comparisons between October 1981 and May 1982 for the atrazine treated plots indicated the failure of the low atrazine rate to release warm-season remnants and the inability of the moderate atrazine rate to maintain adequate cool-season suppression the second year following application. However, the high atrazine rate supported the higher levels of warm-season grasses. These results observed with the moderate rate $(2.2 \mathrm{~kg} / \mathrm{ha})$ of atrazine were similar to the results observed by Waller and Schmidt (1983) for smooth brome.

By the end of the second growing season (October 1982) the percent warm-season grasses had remained the same on the ungrazed, untreated areas and those treated with the low atrazine rate (Fig. 1). However, this level was approximately four-fold greater than May 1982 levels. The grazed control which was outside the exclosure had less than $50 \%$ of the warm-season grass composition compared to the untreated areas within the grazing exclosure. However, regression analysis indicated that only $50 \%$ or less of the variability within the grazing exclosure was a result of atrazine rate. This was a result of the similarity in warm-season grass composition on the untreated control and the lowest atrazine rate. The infuence of the grazing rest was also apparent on the untreated area, with warm-season grasses increasing from $19 \%$ in October 1981 to $36 \%$ in October 1983 . However, this was less than half of the warm-season grass composition on the areas treated with $3.3 \mathrm{~kg} / \mathrm{ha}$ of atrazine. It was apparent that the benefit of atrazine treatment compared to a grazing rest was related to the rate and magnitude of stand conversion.

The shifts in species composition observed in 1981 were not as dramatic in 1982 (atrazine level by time, $P=.14$ ). This indicated that the changes that occurred the first growing season in the proportion of warm- and cool-season grasses had stabilized. However, the high rate of atrazine still resulted in two-fold greater warm-season grass composition than the ungrazed, untreated area and was over five-fold greater than the grazed area. Considering the favorable precipitation for cool-season species in 1982 and the below normal percepitation for the warm-season grasses (Table 1), the warm-season grass response would be expected to be even greater during the more favorable years.

\section{Herbage Yield}

Untreated and treated areas had similar warm-season grass yields at the initial harvest June 1981 (Table 2). Generally, coolseason grass yield was reduced with atrazine application. The herbicide had an immediate effect on cool-season grass yield, particularly the annual brome, while the warm-season response was delayed and variable across treatments. Total yield of the untreated area and that receiving the lowest atrazine rate was similar while the medium and high rates reduced total yield approximately 66 and $75 \%$ respectively.

By August of 1981 areas treated with the higher rates of atrazine had greater warm-season grass and lower cool-season grass yields compared to the untreated and low atrazine rate plots (Table 2). Trends in yield with increasing atrazine rate were consistent with the June harvest data. Total yield had recovered on the plots treated with the higher atrazine rates and there was no difference between treated and unteated areas. The loss of cool-season production in treated plots was compensated by the improved warmseason production.

At the end of the first growing season (October 1981), trends in yield of warm- and cool-season grasses remained unchanged (Table 2). The low rate of atrazine was insufficient to provide any shift in the yield components compared to the untreated area.

Table 2. The effect of different levels of atruxine on big bluestem and indiangrass (warm-season), smooth brome and Kentucky bluegrass (cool-season) and total yield (kg/ha) sampled at three dates within each of two growing seasons. The linear contrast was used to describe the treatment effect.

\begin{tabular}{|c|c|c|c|c|c|c|}
\hline \multirow{3}{*}{ Category } & \multicolumn{6}{|c|}{ Forage yield } \\
\hline & \multirow[b]{2}{*}{ Month } & \multicolumn{4}{|c|}{ Atrazine treatment $(\mathrm{kg} / \mathrm{ha})$} & \multirow{2}{*}{$\begin{array}{c}\text { Linear contrast } \\
(\mathrm{P}>\mathrm{F})^{\mathrm{I}}\end{array}$} \\
\hline & & Untreated & 1.1 & 2.2 & 3.3 & \\
\hline & & & & & \multirow{2}{*}{\multicolumn{2}{|c|}{$-1981-$}} \\
\hline & June & & & & & \\
\hline Total & & 5120 & 5230 & 1820 & 1280 & $<.01$ \\
\hline Warm-season & & 630 & 430 & 1030 & 700 & .40 \\
\hline \multirow[t]{2}{*}{ Cool-season } & & 3970 & 4670 & 770 & 580 & .01 \\
\hline & August & & & & & \\
\hline Total & & 4970 & 4210 & 4710 & 4730 & .72 \\
\hline Warm-season & & 960 & 900 & 3580 & 4320 & .01 \\
\hline \multirow[t]{2}{*}{ Cool-season } & & 3480 & 3300 & 830 & 250 & .01 \\
\hline & October & & & & & \\
\hline Total & & 3810 & 3900 & 5060 & 5160 & .13 \\
\hline Warm-season & & 1170 & 1070 & 4540 & 4920 & .01 \\
\hline \multirow[t]{3}{*}{ Cool-season } & & 2610 & 2800 & 350 & 220 & .01 \\
\hline & & & & & \multicolumn{2}{|c|}{-1982- } \\
\hline & June & & & & & \\
\hline Total & & 2200 & 2190 & 2210 & 2200 & .92 \\
\hline Warm-season & & 890 & 380 & 1390 & 1710 & .01 \\
\hline \multirow[t]{2}{*}{ Cool-season } & & 1270 & 1800 & 810 & 450 & .02 \\
\hline & July & & & & & \\
\hline Total & & 6690 & 5070 & 7120 & 8010 & .15 \\
\hline Warm-season & & 4240 & 2740 & 5990 & 7190 & .01 \\
\hline \multirow[t]{2}{*}{ Cool-season } & & 2315 & 2330 & 1130 & 760 & .01 \\
\hline & September & & & & & \\
\hline Total & & 6000 & 5620 & 6800 & 8110 & .23 \\
\hline Warm-season & & 4090 & 2510 & 5190 & 7290 & .01 \\
\hline Cool-season & & 1860 & 3100 & 1600 & 820 & .01 \\
\hline
\end{tabular}

Contrast coefficients for treatments $0,1.1,2.2$, and $3.3 \mathrm{~kg} /$ ha were: linear $=3-113$ 


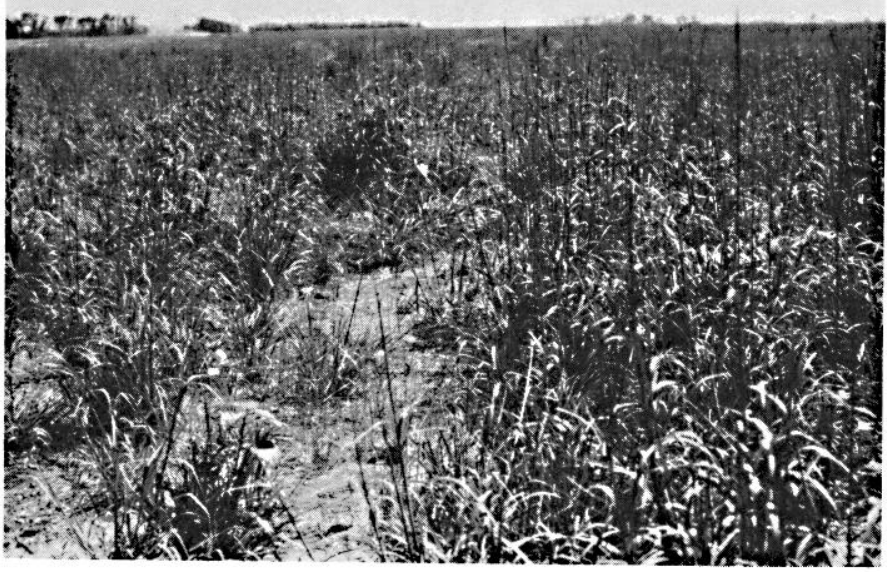

Fig. 2. This pasture was a seeded warm-season pasture which had been dominated by smooth brome and Kentucky bluegrass prior to atrazine application $(2.2 \mathrm{~kg} / \mathrm{ha})$ in April 1982. The vegetation response was evident by July 1982 as indicated by the photograph. Bare ground represents Kentucky bluegrass and smooth brome patches which were suppressed with the herbicide. The estimated yield of warm-season grass was in excess of $5 \mathrm{MT} / \mathrm{ha}$.

However, the 2.2 and $3.3 \mathrm{~kg} / \mathrm{ha}$ rates of atrazine provided shifts from cool- to warm-season components of yield without reducing total yield. Differences between the low and medium atrazine rates were still greater than between the medium and high rates.

The changes during the first growing season in the vegetation yield following atrazine application were consistent with percent composition changes and indicated the complete modification of vegetation dynamics. The proportion of warm-season to coolseason grass yields increased at a much faster rate on the areas treated with the higher atrazine rates (treatment by month interaction, $P=.02$ ). The development of warm-season tillers was encouraged with the atrazine treatment and these tillers appeared vigorous and productive. The magnitude of this response would warrant haying after a frost the year of treatment.

The relationship between yield and atrazine rates established during the first growing season remained 1 year following treatment (Table 2). However the relationship between the untreated area and the area treated with $1.1 \mathrm{~kg} / \mathrm{ha}$ was altered with the untreated consistently having more warm-season and less coolseason grass yield than the area treated with $1.1 \mathrm{~kg} / \mathrm{ha}$. This was first indicated in June 1981 and was observed at all succeeding sample dates. Apparently, the low atrazine rate was sufficient to reduce annual bromes but was ineffective in reducing the vigor of the perennial brome. The very favorable cool-season precipitation for 1982 and reduced competition from annual brome resulted in a more vigorous stand of smooth brome than occurred on the untreated area where annual brome was still abundant. Consequently, smooth brome yield was enhanced by the removal of a cool-season competitor. The smooth brome was an excellent competitor and probably depleted soil moisture prior to warm-season growth initiation.

In July 1982 there was a marked increase in the amount of warm-season grass yield on the untreated area and a slight decrease in cool-season grass yield compared to that of August 1981 (Table 2 ). This was an indication of the response to a grazing rest. Also, it was apparent that the medium atrazine rate was not adequate to prevent the increase of smooth brome the year following treatment. The high atrazine rate resulted in continued improvement in the warm-season grass yield. At the end of the second growing season (September 1982), the relationship between yield components and increasing rates of atrazine was comparable to that of the July 1982 harvest data.

\section{Pasture Demonstration}

Cool-season precipitation was above normal for all 3 years of the pasture demonstration trial (Table 1). Warm-season precipitation was below normal in 2 of the 3 years. Pastures receiving the moderate atrazine rate in 1982 and 1983 exhibited a similar response to that documented in the grazing exclosure (Fig. 2). In both years cool-season grass control was adequate. Kentucky bluegrass and annual bromes were eliminated and smooth brome was reduced by over $50 \%$ based on visual estimates. The warmseason grasses were the dominant vegetation by mid-summer in the year of treatment. However, the second year following treatment there was an increase of smooth brome in pastures, indicating that a single application of the moderate rate was inadequate (L. Brownlee 1984, personal communication). Pastures treated in 1984 at the higher rate had excellent smooth brome control. Visual observation of the pasture demonstrations did support the repeatability of treatment response documented in the grazing exclosure. The estimated cost for herbicide and application was $\$ 25 /$ ha. This compared to a seed cost alone of $\$ 100 /$ ha associated with reseeding native, warm-season grasses.

\section{Conclusion}

A single, spring application of atrazine (3.3. $\mathrm{kg} / \mathrm{ha})$ can renovate smooth brome dominated, seeded warm-season pastures when remmants such as big bluestem are present. It was apparent that seeded warm-season pasture remnants maintain sufficient vigor to respond to a suppression of cool-season competition and increased while cool-season grass percent composition was decreased. A low atrazine rate $(1.1 \mathrm{~kg} / \mathrm{ha})$ was similar to a 2 -year grazing rest in shifting percent composition from cool- to warm-season with the major changes occurring at the end of the second growing season. There was a benefit from the grazing rest alone; however, the addition of the higher rates of atrazine expedited the change. Vegetation treated with the higher rates would not require 2 years of grazing rest. It appeared that the medium atrazine rate was not sufficient to maintain improvement in warm-season grass composition during the second year, which would eventually necessitate a repeated herbicide application. Shifts in species composition were accomplished while maintaining or improving the total yield. This effectively converted a cool-season pasture to a warm-season pasture within 1 year and without a loss in total production.

The use of atrazine is a relatively inexpensive, fast method to convert an abused, seeded warm-season pasture from cool-season dominance to warm-season dominance. The herbicide application cost was less than $\$ 25 /$ ha while the seed cost alone for a conventional reseeding would exceed $\$ 100 /$ ha. When the major invading cool-season species was smooth brome, a high atrazine rate $(3.3$ $\mathrm{kg} / \mathrm{ha}$ ) was required for control. However, $2.2 \mathrm{~kg} / \mathrm{ha}$ was effective the first year for smooth brome suppression and it was sufficient to control Kentucky bluegrass. The success of this practice is dependent on the presence of viable warm-season remnants. It would be advisable to apply the herbicide to small areas protected from grazing before treating entire pastures.

\section{Literature Cited}

Hammer, R.R., L.G. Ragon, and A.A. Buechle. 1981. Soil survey of Clay County, Nebraska. USDA. Soil Conserv. Serv.

Samson, J.R., and L.E. Moser. 1982. Sod-seeding perennial grasses into eastern Nebraska pastures. Agron. J. 74:1055-1060.

Steel, R.G.D., and J.H. Torrie. 1980. Principles and procedures of statistics. 2nd Ed. McGraw-Hill Book Co.

Stroup, W.W., and J. Stubbendieck. 1983. Multivariate statistical methods to determine changes in botanical composition. J. Range Manage. 36:208-212.

Waller, S.S., and D.K. Schmidt. 1983. Improvement of eastern Nebraska tallgrass range using atrazine or glyphosate. J. Range Manage. 36:87-90.

Weaver, J.E. 1965. Native vegetation of Nebraska. Univ. Nebraska Press, Lincoln. 